Olga Gaidai

CZarnomorski Uniwersytet Narodowy

im. Petra MohyŁy w Mikolajowie /

Petro Mohyla Black Sea National University

iD https://orcid.org/0000-0002-7181-9908

TAdeusz SRogosz

Uniwersytet Humanistyczno-PrZyrodniczy

im. Jana Deugosza w Czestochowie /

Jan Dlugosz University in Czestochowa

iD https://orcid.org/0000-0002-1964-8232

\title{
Występowanie i zwalczanie chorób zakaźnych na ziemiach polskich w 1807 roku
}

\section{Abstract}

\section{Occurrence and fighting of infectious diseases in the Polish territories in $\mathbf{1 8 0 7}$}

IN 1807, the greatest health threats to soldiers and civilians resulted from the conducted war. That is why we notice increased incidence and mortality in the base of the fighting French and Polish armies in Pomerania. However, these were not threats on the scale seen before when dealing with plague outbreaks, and later, during cholera epidemics. Health threats mobilized the authorities and the medical community to act. The ordinances issued at that time and the organizational efforts undertaken were directed at both immediate disease control and prevention, as well as creating the foundations for future sanitary and health relations.

Keywords: infectious diseases, occurrence and combating, Polish territories, 1807

\section{STRESZCZENIE}

W 1807 r. największe zagrożenia zdrowotne dla żołnierzy i ludności cywilnej wynikały z prowadzonej wojny. Dlatego zwiększona zapadalność i śmiertelność zauważamy na bezpośrednim zapleczu armii francuskiej i polskiej walczacych 
na Pomorzu. Natomiast nie były to zagrożenia na skalę spotykaną wcześniej, kiedy trzeba było się borykać $z$ epidemiami dżumy, jak również później, w warunkach epidemii cholery. Zagrożenia zdrowotne mobilizowały władze i środowisko lekarskie do działania. Wydane wówczas zarządzenia i podjęte wysiłki organizacyjne kierowane były zarówno na doraźne zwalczanie i zapobieganie chorobom, jak i tworzenie zrębów przyszłych stosunków sanitarno-zdrowotnych.

Słowa kluczowe: choroby zakaźne, występowanie i zwalczanie, ziemie polskie, 1807

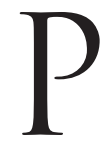

roblematyka opieki społecznej i zdrowotnej na ziemiach polskich w 1807 r. była już przedmiotem badań, których najważniejszym efektem stała się monografia z 2001 r. ${ }^{1}$ Truizmem jest stwierdzenie, że wojna i choroby ida w parze, co znalazło odzwierciedlenie w znanej modlitwie „Od powietrza, głodu, ognia i wojny wybaw nas, Panie”. Według Wiktora Bincera niekorzystna sytuacja epidemiczna w armii spowodowana była m.in. koncentracją w jednym miejscu dużej liczby osób, wyczerpaniem żołnierzy na skutek niedożywienia i trudów służby wojskowej, niskim stanem higieny, niedostatecznie szybką izolacją chorych (szczególnie w czasie przemarszów) oraz słabo zorganizowana wojskową służba medyczna ${ }^{2}$. Na ziemiach polskich w 1807 r. przebywały armie: francuska, pruska, rosyjska, polska i oddziały sprzymierzone (np. bawarskie), co razem stanowiło kilkaset tysięcy żołnierzy. Nawet po pokoju w Tylży cesarz Napoleon zobowiązał polskie władze do utrzymywania 80000 żołnierzy (45 000 korpusu francuskiego, 30000 armii polskiej i 5000 kontyngentu saskiego), co znacznie przekraczało możliwości nowo utworzonego Księstwa Warszawskiego ${ }^{3}$. $\mathrm{W}$ tej sytuacji mnożyły się rekwizycje pożywienia i paszy, rabunki, dewastacja środków produkcji i sprzętów domowych, migracje, ciasnota zamieszkania $z$ powodu kwaterunku żołnierzy.

Zakresem terytorialnym pracy jest obszar, którym zarządzał tymczasowy rząd polski od 14 stycznia 1807 r. do 5 listopada 1807 r., czyli Komisja Rządząca. Ten właśnie obszar nazywano wówczas „Polską na królu pruskim zdobytą".

${ }_{1}$ T. Srogos z, Pomoc weteranom, rannym i chorym na ziemiach polskich $w$ latach 1806-1807, Częstochowa 2001.

${ }^{2}$ W. Bincer, Wojny i choroby zakaźne (Z rozważań epidemiologicznych), Cieszyn 1946 , s. 12-13.

${ }^{3}$ B. Szyndler, Stanisław Nałęcz Małachowski 1736-1809, Warszawa 1979, s. 295. 
Mimo wyżej zarysowanych warunków w 1807 r. armiom działajacym na tym terytorium nie zagroziła poważnie żadna epidemia chorób zakaźnych. Władze i wojskowa służba zdrowia były jednak czujne, tym bardziej że od czasu do czasu krążyły informacje o zarazie wśród ludności cywilnej. Dopiero latem 1807 r. płk Jan Bennet, który obozował pod Marymontem ze swoja jednostka, prosił, aby przysłano mu ocet i wódkę w celach profilaktycznych. Dnia 13 sierpnia 1807 r. Komisja Rządzaca poleciła dyrektorowi spraw wewnętrznych Stanisławowi Brezie, aby dostarczył 100 garncy $^{4}$ octu i 50 garncy wódki, ,a to w celu zapobieżenia skutkom zagraża-

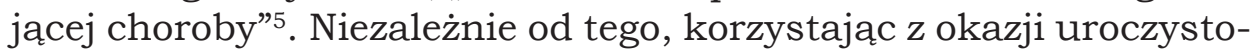
ści związanych $z$ urodzinami cesarza Napoleona, rozprowadzono wówczas znaczna ilość wódki i octu winnego w garnizonie warszawskim oraz $\mathrm{w}$ jednostkach stacjonujacych na prowincji. Taka sama procedurę zastosowano niespełna miesiąc później w stosunku do pułku stacjonującego w Pułtusku. Miały tam panować biegunka, zgniła febra i czarne petocie. Pod tym ostatnim schorzeniem rozumiano objaw różnych jednostek chorobowych, zwłaszcza zaś dżumy i tyfusu. Tym chorobom „wedle zdania doktorów najskuteczniej octem i okowitka zaradzić można"6. Prawdopodobnie w związku $z$ tymi incydentami dyrektor wojny, książę Józef Poniatowski, zawnioskował 21 września 1807 r. do Komisji Rządzącej o przeznaczenie kwoty 30000 zł na mundury i płaszcze dla wojska, ponieważ kilkaset kompletów, zgodnie z zaleceniami lekarzy i chirurgów, zostało spalonych w lazaretach jako stanowiących własność chorych dotkniętych „zaraźliwą chorobą"

Dane dotyczace zapadalności w wojsku polskim sa jedynie wyrywkowe, dotycza Warszawy, i to tylko kilku lazaretów umieszczonych w domach prywatnych. Od 3 kwietnia 1807 r. naczelny lekarz wojska polskiego, doktor Michał Bergonzoni zaczął opracowywać dzienne raporty pt. Poruszenie lazaretu polskiego będacego $w$ domach $z$ choremi 1, 2, 3 i 4 Reg. (później pułku) Legii I i artylerii

${ }^{4}$ Garniec warszawski - 3,77 1 (J. Szymański, Nauki pomocnicze historii, Warszawa 2001, s. 170).

${ }^{5}$ Archiwum Główne Akt Dawnych w Warszawie [dalej: AGAD], Archiwum Komisji Rządzącej [dalej: AKR], nr I.6, s. 51; nr I.8, s. 2; nr II.41, s. 161. Franciszek Giedroyć podał mylnie, że tę decyzję podjął Dyrektoriat Generalny (Służba Zdrowia $w$ dawnem Wojsku Polskiem, Warszawa 1927, s. 62), podczas gdy Komisja Rządząca powróciła już wówczas $z$ Drezna.

${ }^{6}$ AGAD, AKR, nr I.17, s. 33; AKR, nr I.22, s. 43; nr II.41, s. 64-65.

7 AGAD, AKR, nr II.55, s. 80. 
$w$ Warszawie (od 1 sierpnia 1807 r. raport ten dotyczył Legii I i III, natomiast od 4 sierpnia tego roku wszystkich legii) ${ }^{8}$. Były one podpisywane nie tylko przez doktora Bergonzoniego, lecz także przez protochirurga wojska polskiego, doktora Leopolda Lafontaine'a, a następnie były przekazywane członkowi Komisji Rządzącej Walentemu Sobolewskiemu. Raporty sa wprawdzie wyrywkowe, ale dokładne, a w związku $z$ tym dające pewien obraz zapadalności na poszczególne choroby.

W raportach dla komisarza Sobolewskiego ich twórcy podzielili choroby na wewnętrzne i zewnętrzne według następujących kategorii: febris catharalli (goraczka kataralna), febris nervosa (silna gorączka), febris biliosa (gorączka żółciowa), febris intermittens (goraczka wewnętrzna), diarhorea (biegunka), peripneumonia (zapalenie płuc), pyelitis (zapalenie miedniczek nerkowych), hydrops (puchlina wodna), inflam. guttur (zapalenie gardła), inflam. oculor (zapalenie oka), epilepsja (padaczka), rheumatism (choroby reumatyczne), debilitatio (osłabienie), scabies (świerzb), ulcera lub scrophule (wrzody), vulnera (rany i obrażenia), tumor chronic. (guz przewlekły), morb. veneri (choroby weneryczne) oraz rekonwalescenci. Mimo kształtujacej się od XVII w. wraz z medycyna kliniczna nozologii nie były to jeszcze precyzyjnie określone jednostki chorobowe, dlatego też podane w nawiasach wyjaśnienia nie muszą ściśle odpowiadać wyobrażeniom ówczesnych lekarzy i chirurgów. Raporty sa w porównaniu $z$ innymi materiałami $z$ tego okresu lub nawet późniejszymi i tak bardziej rozbudowane i dokładniejsze9.

W raportach doktorów Bergonzoniego i Lafontaine'a pod pojęciem chorób kryją się w znacznej części objawy, które mogą znamionować choroby zakaźne. Na gorączki cierpiało niezależnie od pory roku $50-60 \%$ pacjentów lazaretów warszawskich. Współcześnie goraczka jest objawem wielu chorób, w tym może być symptomem chorób zakaźnych. Natomiast zapalenie płuc, zapalenie miedniczek nerkowych, zapalenie gardła, zapalenie oka najczęściej maja podłoże bakteryjne lub wirusowe. Zapadalność na świerzb miała $z$ biegiem czasu tendencję zwyżkowa (13-25\%). Na wzrost występowania tej choroby zakaźnej zapewne wpływało zgrupowanie w jednym miejscu dużej liczby osób, co nie dotyczyło wprawdzie

8 AGAD, AKR, nr II.92.

9 Z. Jastrzębowski, Polska statystyka medyczna a badania nad zdrowotnościa społeczeństwa polskiego w XIX wieku, „Medycyna Nowożytna. Studia nad Historia Medycyny" 1996, t. III, z. 1-2, s. 117-123. 
izolacji w lazaretach, lecz w koszarach i na kwaterach. Znaczna też była liczba chorych na biegunkę (3-9\%), która jest objawem różnych schorzeń. Tutaj można dodać podobny komentarz jak w przypadku goraczek. To samo dotyczy takich przypadków, jak: puchlina wodna, osłabienie, wrzody, przewlekły guz. Przykładowo czyraczność jest chorobą zakaźna, ale nie zaraźliwą. Puchlina wodna jest wprawdzie pojęciem historycznym, ale mogła ona być objawem sepsy, która jest gwałtowna reakcją zapalną organizmu na zakażenie wywołane najczęściej bakteriami oraz ich toksynami, rzadziej wirusami i grzybami. Duża liczba żołnierzy cierpiących na choroby reumatyczne (2-7\%) wynikała zapewne ze złych warunków bytowania. Ich podłożem moga być zakażenia. Mniej więcej w tym samym przedziale utrzymywała się liczba chorych wenerycznie. Odbiegało to znacznie od danych $z$ końca XVIII w. Ludwik Perzyna pisał wówczas: „Rekruci, ze wsiów do regimentów i pułków po miastach stojących oddawani, zachwyciwszy wprzód sami tej zarazy w miastach, idąc za urlopami na wsie oręż roznosza $z$ sobą i nią włościanki zarażaja" ${ }^{10}$. O dużym problemie chorych wenerycznych pisali również inni lekarze oraz publicyści. Według Franciszka Giedroycia w 1791 r. wśród 100 rekrutów sprowadzonych ze wsi do Warszawy 80 cierpiało na choroby weneryczne ${ }^{11}$. Tę duża rozbieżność danych statystycznych można wyjaśnić albo wyolbrzymianiem przez lekarzy i publicystów oraz literaturę przedmiotu, albo znacznym spadkiem zapadalności na "francę" w ciagu kilkunastu lat.

Nie można też zapominać o chorobach zakaźnych zwiąanych ze skutkami krwawych bitew epoki napoleońskiej. Późniejszy porucznik 12 pułku piechoty Antoni Białkowski pisał o bitwie pod Friedlandem: „W miarę zbliżania się napotykaliśmy coraz więcej leżących przy drodze, jednych konających, drugich jeszcze cokolwiek żyjacych. Każdy tak zrąbany, że nie tylko głowy, ale nawet ręce i palce poobcinane mieli" ${ }^{2}$. Według obliczeń Borysa Cezarewicza Urłanisa, który oparł swoje dane na solidnych podstawach historiografii europejskiej (zwłaszcza francuskiej), w latach 18051815 padło na polach bitew i zmarło w wyniku otrzymanych ran we wszystkich armiach 755000 osób, liczba rannych wyniosła

10 L. Perzyna, Lekarz dla włościan, Warszawa 1793, s. 319-320.

11 F. Giedroyć, Rys historyczny szpitala św. Łazarza w Warszawie, Warszawa 1897 , s. 172 .

12 A. Białkowski, Pamiętniki starego żołnierza, Gdynia 2003, s. 42. 
1964 000, a ogólna liczba zabitych i zmarłych w wojnach europejskich w latach 1800-1815 przewyższała $3600000^{13}$. Według tego autora straty armii francuskiej i wojsk sojuszniczych w latach 1806-1807 w Prusach i na ziemiach polskich wynosity 32000 poległych i zmarłych od ran oraz 93700 rannych $^{14}$. Christoper Summerville stwierdził, że straty w ludziach poniesione w czasie polskiej kampanii napoleońskiej trudno oszacować, „Można jednak $z$ cała pewnościa powiedzieć, że Wielka Armia poniosła mniej ofiar niż połączone armie pruska i rosyjska. W przybliżeniu mówi się nawet o 50 procentach"15. Najkrwawsza była bitwa pod Pruska Iława, która James R. Arnold i Reinertsen R. Ralp określili „bezsensowna rzezią"16. Tomasz Rogacki obliczył straty po stronie francuskiej: 4000 zabitych (w tym 286 oficerów), 9000 rannych (w tym 661 oficerów) i 5000 jeńców; natomiast po stronie rosyjskiej: 8000 zabitych, 5000 rannych pozostawionych na pobojowisku, 12000 rannych zabranych ze soba, 3000 jeńców ${ }^{17}$. Inni autorzy podaja jeszcze wyższe straty po obu stronach. Rany często prowadziły do bardzo skomplikowanych powikłań, np. krwotoków wtórnych (zwane poślednimi), dreszczy, gorączki, bóli oraz zapaleń nadmiernych (róże) czy wreszcie najcięższych, tj. zgorzeli, inaczej gangreny (zwanej ogniem piekielnym), i tężca (określanego jako „trętwiec”) ${ }^{18}$. Części $z$ tych przypadków chorobowych nie potrafimy zidentyfikować $z$ racji ich objawowego charakteru, część natomiast to choroby zakaźne, ale nie zaraźliwe lub zaraźliwe w minimalnym stopniu (róża, zgorzel, tężec). Na powyższe przypadki ówcześni medycy stosowali głównie preparaty roślinne, np. na gangrenę maści, a także specjalny specyfik wstrzykiwany $\mathrm{w}_{\text {rany }}{ }^{19}$.

${ }^{13}$ B.C. Urłanis, Wojny a zaludnienie Europy, Warszawa 1962, s. 79, 329.

${ }^{14}$ Ibidem, s. 75.

15 Ch. Su m m erville, Polska kampania Napoleona, przekł. M. Łakomy, Warszawa 2008, s. 201.

16 J.R. Arnold, R.R. Ralp, Kryzys w śniegu. Kampania zimowa 1806-1807. Wielka Armia przeciwko Armii Carskiej, przekł. M. Rukat, red. M. Promis, Oświęcim 2014, s. 343.

17 T. Rogacki, Pruska Iława 1807, Warszawa 2004, s. 97-98; id e m, I wojna polska 1806-1807, t. I (Od manewru pułtuskiego do kampanii zimowej $w$ Prusach Wschodnich), Zabrze 2015, s. 272-275.

18 E. Grzelak, Chirurgia polowa $w$ Księstwie Warszawskim i Królestwie Polskim, „Studia i Materiały do Historii Wojskowości” 1970, t. XVI, cz. 1, s. 182-187.

${ }_{19}$ M. Baranowski, Chleb z pajeczyna czy "species vulnerariae”? - leczenie ran w wojskach Księstwa Warszawskiego w świetle „Przepisów lekarstw”, „Teka Komisji Historycznej Oddział Lublin PAN” 2010, t. VII, s. 74, 76. 
Ukształtowanie się nozologii nie rozwiązało dylematów związanych $z$ przyporządkowaniem konkretnych objawów do danej tzw. jednostki chorobowej. Do dziś zresztą nie straciły na aktualności spostrzeżenia Ludwika Flecka na temat swoistych cech myślenia lekarskiego ${ }^{20}$, które pobrzmiewały w różnych pismach i różnych epokach. W artykule z 1927 r. Fleck wskazał na różnice między przedmiotem poznania lekarskiego a przedmiotem poznania przyrodniczego. Przyrodnik poszukuje zjawisk typowych, normalnych, natomiast lekarz nietypowych, nienormalnych. Lekarz napotyka ogromne bogactwo i indywidualność zjawisk, które zawieraja dużo stanów przejściowych, granicznych. Zadaniem medycyny jest poszukiwanie praw dla zjawisk nieprawidłowych. W ten sposób tworzy się idealne, fikcyjne typy, zwane jednostkami chorobowymi, wokół których grupuja się indywidualne i zmienne zjawiska patologiczne. W związku $z$ tym w medycynie, oprócz statystycznego zestawienia i porównywania wielu podobnych faktów, ogromna rolę odgrywa swoista intuicja. W żadnej innej poza medycyna wiedzy nie ma tylu specyficznych cech, które nie dają się zanalizować, sprowadzić do wspólnych elementów. Wskutek tego istnieje charakterystyczna rozbieżność teorii i praktyki, tzn. nie sztuki i nauki lekarskiej, lecz wiedzy książkowej i żywych obserwacji. Podobnie jak inne nauki przyrodnicze medycyna uznaje zwiazki przyczynowe, lecz skutek nie jest nigdy proporcjonalny do przyczyny ani nawet stale taki sam. Wynikaja $z$ tego ważkie konsekwencje: konieczność ciagłej zmiany kąta patrzenia, niewspółmierność idei, niemożliwość istnienia idei obejmującej całokształt wiedzy medycznej, łatwość pseudologicznego tłumaczenia zjawisk.

Przez cały omawiany okres w armii polskiej utrzymywał się wysoki stan chorych lub uchylajacych się od służby wojskowej. Interesował się tym faktem sam cesarz Napoleon. Grając 4 kwietnia 1807 r. w kwaterze głównej w Kamieńcu w karty z Józefem Wybickim, wyraźnie wypytywał o przyczyny chorób i dezercji żołnierzy polskich ${ }^{21}$. Napoleon miał podstawy, aby podejrzewać, że znaczna

${ }^{20}$ L. Fleck, O niektórych swoistych cechach myślenia lekarskiego, „Archiwum Historii i Filozofii Medycyny" 1927, t. VI, s. 55-64. Jest to praca pozostajaca w cieniu analizy Flecka na temat stylów myślowych i kolektywów myślowych, aczkolwiek istotna. Szerzej: T. Srogos z, Między biologiczna egzystencja człowieka $w$ dziejach a historia nauki, Częstochowa 2003, s. 164.

${ }^{21}$ Archiwum Wybickiego, t. II (1802-1822), wyd. A.M. Skałkowski, Gdańsk 1950, s. 149. Por. W. Zajews ki, Józef Wybicki, Warszawa 1977, s. 191. 
część żołnierzy uchyla się od służby wojskowej, dlatego oficjalnie interweniował $\mathrm{w}$ tej sprawie u komisarza Komisji Rządzącej przy cesarzu Aleksandra Batowskiego. Dawne badania Leona Antoniego Sułka na temat dezercji $z$ wojska Księstwa Warszawskiego ilustruja dużą skalę tego procederu ${ }^{22}$. Po epizodzie karcianym w Kamieńcu i oficjalnej interwencji władze polskie podjęły usilne starania, aby zmniejszyć liczbę chorych, np. zwalniając rekonwalescentów $z$ lazaretów. Mimo to liczba chorych żołnierzy oscylowała i dochodziła do 8552, co więcej, nawet po zakończeniu działań wojennych wynosiła około $20 \%$ stanu całej armii narodowej ${ }^{23}$.

Przyczynami śmierci pacjentów w lazaretach warszawskich według raportów przygotowanych przez doktorów Bergonzoniego i Lafontaine’a były najczęściej gorączki, rzadziej biegunka, zapalenie miedniczek nerkowych i puchlina wodna. Śmiertelność kształtowała się na bardzo niskim poziomie i wynosiła dziennie do kilku osób (na ponad 1000 pacjentów). Feliks Łubieński, składając jako przewodniczący raporty o czynnościach Dyrektoriatu Generalnego podczas pobytu Komisji Rządzącej w Dreźnie za okres od 13 lipca 1807 r. do 25 lipca 1807 r. pisał, że w lazaretach nikt nie umarł, raz doniósł o śmierci jednego żołnierza, częściej odnotowywał, że „mało co umiera" ${ }^{24}$. W prowizorycznych lazaretach głównych w Tokarach i Dobrzykowie, zorganizowanych w magazynach nad Wisła, śmiertelność również kształtowała się na niskim poziomie. Członkowie Komisji Lazaretowej w liście do Józefa Wybickiego z 16 czerwca 1807 r. pisali: „Śmierć zmniejszyła znacznie swoją moc, z 1600 chorych dzisiaj nie umarło jak tylko 6, gdy niedawno od 14 do 15 na dzień umierało i to $z$ daleko mniejszej liczby" 25 .

Według raportu generalnego intendenta Wielkiej Armii, hrabiego Pierre'a Daru śmiertelność w lazaretach wynosiła 7,5\%, co Jerzy Krzyś i Tadeusz Srogosz przyjęli szacunkowo dla wojska polskiego $^{26}$. $Z$ cała pewnościa nie sa to wartości podane przez innych autorów. Mianowicie Franciszek Giedroyć podał, że w roku 1807

${ }^{22}$ L.A. Sułek, Dezercja z wojsk Księstwa Warszawskiego (lata 1807-1813), „Kwartalnik Historyczny” 1988, nr 3, s. 173-198.

${ }_{23}$ T. Srogos z, Pomoc weteranom..., s. 52-53.

${ }^{24}$ Materyały do dziejów Komisyi Rządzacej z r. 1807, t. I (Dziennik czynności Komisyi Rządzącej), wyd. M. Rostworowski, Kraków 1918, s. 319-331.

25 Archiwum Wybickiego..., s. 216.

${ }^{26}$ J. Krzyś, Służba zdrowia wojsk polskich w latach 1806-1807, Łódź 1978 (rozprawa doktorska w Bibliotece Wydziału Wojskowo-Lekarskiego Uniwersytetu Medycznego w Łodzi), s. 61; T. Srogos z, Pomoc weteranom..., s. 51. 
dur dziesiątkował wojsko ${ }^{27}$, natomiast Robert Bielecki stwierdził, że personel medyczny nie był w stanie zapewnić właściwej opie$\mathrm{ki}$, stąd w lazaretach panowała wysoka śmiertelność ${ }^{28}$. Ówcześni medycy posługiwali się wprawdzie innym nazewnictwem, prymitywniejszymi narzędziami, nie znali zasad antyseptyki i aseptyki, działali w innym otoczeniu etc., ale widocznie umieli sobie radzić $z$ rannymi i chorymi żołnierzami.

Dla ludności cywilnej nie mamy takich dokładnych, aczkolwiek wyrywkowych danych. Dlatego musimy opierać nasze opisy i interpretacje na ówczesnej korespondencji urzędowej, zawierającej tylko informacje o bardziej masowych zagrożeniach epidemiami i epizootiami. Natomiast władze, ale także ogół ludności rozumiał tę współzależność między wojną a „powietrzem”. Dlatego zagrożenie epidemiczne uważano za pierwszoplanowe. Do czerwca $1807 \mathrm{r}$. choroby nie nasiliły się $\mathrm{w}$ takim stopniu, aby te zjawiska uznać za epidemie. Mimo to władze oraz doktor Lafontaine przestrzegali ludność przed zagrożeniem epidemicznym, wskazując na źródła zakażeń, czyli pobojowiska, cmentarze i szpitale. Dnia 22 lutego 1807 r. Komisja Rządząca zaleciła Izbie Administracji Publicznej departamentu warszawskiego, aby podjęła działania zapobiegajace zarazie, która może wybuchnać wiosna w pobliżu cmentarza na Powazkach ${ }^{29}$. Doktor Lafontaine przestrzegał władze przed możliwością wybuchu epidemii $z$ powodu zaniechania grzebania zwłok $z$ pobojowisk ${ }^{30}$. Problem dużej liczby rannych i grzebania zwłok przewijał się przez całą epokę napoleońską (zresztą nie tylko wówczas). Przykładowo po bitwie pod Austerlitz „pojedynczo już ciał nie grzebano, ale wywiezione na smętarz $\mathrm{w}$ dołach po kilkadziesiąt trupów w jednym warstwami układano, wapnem niegaszonym przysypywano i ziemia gruba przykrywano"31. W różnych epokach bywało jeszcze gorzej, łacznie $z$ pozostawieniem pobojowisk na pastwę dzikim lub zdziczałym zwierzętom. Doktor Lafontaine przestrzegał również przed kolejnym źródłem rozprzestrzeniania się chorób, czyli przed szpitalami, przepełnionymi chorymi żołnierzami, niedożywionymi i niedostatecznie odzianymi. Według niego ta sytuacja dotyczyła zwłaszcza licznych jeńców rosyjskich.

${ }^{27}$ F. Giedroyć, Stużba Zdrowia..., s. 75.

28 R. Bielecki, Wielka Armia, Warszawa 1995, s. 194.

29 AGAD, AKR, nr I.10, s. 8.

${ }^{30}$ Materyały do dziejów Komisyi Rządzacej..., s. 109; AGAD, AKR, nr I.18, s. 15.

31 J. Jas zow ski, Pamiętnik dowódcy rakietników konnych, Warszawa 1968, s. 34. 
Komisja Rządząca przekazała sprawę dyrektorowi policji Aleksandrowi Potockiemu, który miał uzgodnić z doktorem Lafontaine'em metody zapobiegawcze. Zobowiązano również dyrektora Potockiego do wydania zarządzenia o pochówku zwłok w okolicy Pomiechowa i Czarnowa nad Narwia oraz trupów koni za Praga w kierunku Jabłonnej i Nieporętu ${ }^{32}$.

Doktor Lafontaine na zlecenie dyrektora policji Potockiego opracował wskazówki profilaktyczne, które w formie odezwy do publiczności ogłosiła 11 kwietnia 1807 r. w prasie Izba Administracji Publicznej departamentu warszawskiego: „Nalać w filiżankę porcelanową blisko łót zkoncentrowanego kwasu siarczystego, czyli jak powszechnie nazywają olejku witriowego (Oleum vitrioli, acidum Vitrioli concentratum). Ta filiżanka stawia się na talerzu glinianym, w piasku dobrze ogrzanym; za ogrzaniem kwasu siarczystego, wsypuje się powoli blisko pół łóta utartej saletry i miesza szklanym lub drewnianym prętem, po niejakim czasie wznosi się znaczna para i po izbie rozchodzi. Filiżanki nie należy przybliżać do chorego. Podczas kadzenia drzwi i okna zamknać i po godzinie dopiero dla odmiany powietrza otworzyć; kadzi się raz lub dwa razy na dzień. Chodzący koło tego winien się strzec, aby kwas siarczysty nie wylał się na ciało lub na szaty, gdyż uszkodzonemi być moga, utrzymuje się zaś najlepiej w naczyniu szklanym, a lepiej jeszcze w kamiennym, jak butelki do wody salcerskiej, dobrze zatkanym. Ochędóstwo, powietrze czyste, pewna ostrożność w przybliżaniu się do chorych, osobliwie chronienie się ich potu, oddechu, śliny i rzeczy wszelkich, które tym nasiaknąć by mogły, umysł swobodny, praca umiarkowana, mierne używanie wina, wódki lub araku są niejako ochraniajacemi od zarazy lekarstwami"33.

Zalecenia doktora Lafontaine'a były typowe, oparte na ówczesnym stanie wiedzy, stosowane w profilaktyce i leczeniu chorób zakaźnych zarówno wcześniej, jak i później. Do sukcesów bakteriologii i wirusologii funkcjonowały dwie główne teorie o zaraźliwości. Teorię zakażenia, pojawiająca się wprawdzie w formie praidei od starożytności, rozwinął włoski lekarz Girolamo Fracastoro w trzytomowym dziele De contagionibus et contagionis morbis (1546). Twierdził on, że zarazę powoduja „seminaria”, niewidzialne gołym okiem cząsteczki. Fracastoro rozróżnił trzy rodzaje zakażeń: per

32 AGAD, AKR, nr I.5, s. 362.

33 „Gazeta Korrespondenta Warszawskiego i Zagranicznego” 1807, nr 30, s. 382; „Gazeta Warszawska” 1807, nr 30, s. 465-466. 
contagium, czyli bezpośrednio przenoszone $z$ człowieka na człowieka; per fomitem, czyli przenoszone pośrednio przez rzeczy (np. odzież i naczynia) oraz przenoszone na odległość (zakażenie odbywa się głównie w czasie oddychania). Zwolenników teorii Fracastoro nazywano kontagionistami. W XVII w. lekarz angielski Thomas Sydenham, wykorzystując $z$ kolei praideę miazmatów (szkodliwych wyziewów), stworzył teorię tzw. konstytucji epidemicznej. Zdaniem Sydenhama miazmaty powodowały, że różne objawowe choroby goraczkowe stawały się złośliwe, przyjmując epidemiczna postać. Teorie te przyczyniły się do rozpoznawania, klasyfikacji i profilaktyki różnych jednostek chorobowych.

Obawy doktora Lafontaine'a znalazły potwierdzenie w czerwcu 1807 r., kiedy w Mławie i jej okolicach wybuchła epidemia. Według Izby Administracji Publicznej departamentu płockiego, która posiłkowała się opinia mławskiej Izby Wykonawczej, panowała na tym terenie dyzenteria (czerwonka) spowodowana niedożywieniem (miejscowa ludność odżywiała się zielenina $z$ racji braku innych możliwości pokarmowych), dużą liczbą chorych w lazaretach i wielką liczbą świeżych mogił ${ }^{34}$. Departament płocki znajdował się od kilku miesięcy na bezpośrednim zapleczu działań wojennych. Rekwizycje i rabunki ogołociły ten obszar z żywności, zwłaszcza ze zboża. Polskie władze zwracały się wielokrotnie do dowództwa francuskiego $z$ prośbami, aby żołnierze nie zabierali chociaż ziarna na zasiewy. W dniu 8 czerwca 1807 r. pełnomocnik Komisji Rządzącej na prawym brzegu Wisły Józef Wybicki pisał: „Choroby w Mławie rozszerzyły się bardzo, prawda, ale $z$ nieroztropności komendanta placu, Polaka, który przychodzacych chorych i zarażonych $z$ obozu lokował po domach ubogich obywateli. Zagroziłem mu kasacja, a dla przybywajacych chorych wybrałem na wzgórku lazaret, Starościński nazwany. Te i inne urządzenia zakończą epidemię" 35.

Prognoza Wybickiego odnośnie do zakończenia epidemii nie w pełni się sprawdziła. Dnia 12 czerwca $1807 \mathrm{r}$. otrzymał on list o alarmującej treści: „Podług uczynionej rewizji przez kreisfizyka Loebera znajduje się $\mathrm{w}$ tutejszym mieście jeszcze $z$ mieszkańców 218 osób chorych, pomiędzy któremi jednak znaczna część do zdrowia przychodzi, a przez przeciag czasu tej choroby umarło 59. Gatunek choroby najwięcej zgniła goraczka i petocje (czerwona wysypka tyfusowa - przyp. wydawcy), które i okolicznie a osob-

${ }^{34}$ AGAD, AKR, nr II.62, s. 87; Archiwum Wybickiego..., s. 202.

35 Ibidem, s. 209. 
liwie na trakcie $\mathrm{w}$ położonych wsiach panują. Wieś Uniszki Zawadzkie, Kuklin, Kulaszy (wsie starostwa mławskiego - przyp. wydawcy), najmocniej są tą klęską tknięte, i w pierwszej, gdzie 24 gospodarzy mieszka, umarło już 31 osób, w Kuklinie i Kulaszach składajacych 36 dymów choruje teraz 63 osoby. Jednak choroba nie zabiera tyle ludzi jak w pierwszej, gdy do tej pory tylko 19 osób umarło. Po innych wsiach okolicznie, jak to w Łomi (Łomnia przyp. wydawcy), Woli Łomskiej, Karbońcu, Wiszniewie (Wiśniowiec - przyp. wydawcy), Otoczni, Studzieńcu, Nowej Wsi, Modle (Modła - przyp. wydawcy), Półkraciwci (Podkrajewo - przyp. wydawcy) i Wojnówce, lubo ludzie też choruja, to jednak nie tak znacznie i mało co umiera, a używanie tyzanny (tyzanna lub tyzana napar z leczniczych ziół - przyp. O.G. i T.S.) z octów (z ostów - przyp. wydawcy) najwięcej onych ratuje. $Z$ lazaretu tutejszego chorzy już tak dalece zostali wywiezieni, że na dniu przedwczorajszym tylko 137 chorych zostało, lecz przez wczorajszy i dzisiejszy 189 chorych $z$ Neidenbergu [Nidzica - przyp. O.G. i T.S.] przybyło..." ${ }^{36}$. $Z$ listu wynika, że rozmiary epidemii malały. Natomiast nadawca przestrzegał, że umieszczanie dalszych chorych żołnierzy w lazarecie mławskich mogło prowadzić do zagrożenia zdrowia ludności cywilnej.

Sytuacja epidemiczna w Mławie i okolicy zaalarmowała władze lokalne i centralne. Sprawa interesowali się zwłaszcza dyrektor spraw wewnętrznych Stanisław Breza i dyrektor policji Aleksander Potocki. Pełnomocnik Komisji Rządzącej na prawym brzegu Wisły Józef Wybicki zaangażował do akcji ratunkowej nie tylko kreisfizyka (lekarza powiatowego) Fryderyka Loebera, lecz także prosił warszawskiego lekarza, doktora Hiacynta Dziarkowskiego, przebywającego wówczas na inspekcji lazaretu w Tokarach i Dobrzykowie, aby podją działania lecznicze i profilaktyczne. Dnia 28 czerwca 1807 r. dyrektor Breza polecił mławskiej Izbie Wykonawczej, aby wysłała chirurga do dóbr narodowych Łomnia w celu zapobiegania szerzacej się tam epidemii wśród ludzi i epizootii wśród zwierząt ${ }^{37}$. Sytuacja widocznie została opanowana, ponieważ przez pewien czas w źródłach nie odnotowujemy wzmianek na ten temat.

Następna fala zwiększonej zapadalności na choroby zakaźne w departamencie płockim nastąpiła w miesiącach sierpień-wrze-

${ }^{36}$ Ibidem, s. 209-210.

37 AGAD, AKR, nr I.188, s. 129. 
sień 1807 r., czyli już po zakończeniu działań wojennych. Mimo to pozostały negatywne okoliczności, które składały się na zagrożenie epidemiczne. Dawała wtedy jeszcze o sobie znać sytuacja $z$ przednówka, kiedy ludność przymierała głodem, zwłaszcza w okolicach Ostrołęki, Pułtuska i Mławy ${ }^{38}$. Nie zaniechano też rekwizycji wojskowych, a najgorzej zachowywali się żołnierze VI korpusu francuskiego marszałka André Massény, księcia Rivoli. Po pokoju w Tylży rozprzężenie w armiach francuskiej i polskiej się nasiliło. Dyrektor wojny, książę Józef Poniatowski i inni wyżsi oficerowie osobiście patrolowali ulice Warszawy, aby zapobiegać rozpasaniu żołdactwa. Dopiero energiczne działania marszałka Louisa Nicolasa Davouta, mianowanego naczelnym dowódca wszystkich wojsk stacjonujących na wschód od Odry, przyniosły częściowe ograniczenie nadużyć żołnierskich.

Niekorzystnie na sytuację epidemiczną w departamencie płockim oddziaływało przepędzenie przez Francuzów w okolice Warszawy 1000 sztuk wołów z Prus. Wkrótce padły one wskutek zarazy, uratowano zaledwie 200 sztuk $^{39}$. Przymierajacy głodem chłopi spożywali mięso $z$ padłego bydła, co stało się przyczyną głównie dyzenterii. Rozumiejąc powage sytuacji, Komisja Rządzacca upoważniła 17 sierpnia 1807 r. dyrektorów Brezę i Potockiego do wydania polecenia Izbie Administracji Publicznej departamentu płockiego, aby utrzymała tymczasowo do czasu ustanowienia Kolegium Medycznego dotychczasowych kreisfizyków (lekarzy powiatowych) i chirurgów, opłacając ich według etatu rządu pruskiego ${ }^{40}$. Uznano, że tylko takie rozwiazanie może zapobiec katastrofie. Mimo to zaraza bydła i epidemia dyzenterii wśród ludzi się rozszerzała, aczkolwiek w tempie umiarkowanym. Według opinii Stanisława Jabłonowskiego i Franciszka Twardowskiego, komisarzy wyznaczonych do rozgraniczenia Księstwa Warszawskiego i Królestwa Pruskiego, na przełomie sierpnia i września $1807 \mathrm{r}$. epidemia osiągnęła znaczne rozmiary w okolicach Bydgoszczy, Torunia i Elblaga ${ }^{41}$. Chłopi umierali tam masowo, co krok komisarze widzieli kondukt pogrzebowy. Dlatego przenieśli oni swoją siedzibę z Bydgoszczy do Chełmna.

\footnotetext{
${ }^{38}$ W. Zajewski, op. cit., s. 193.

${ }^{39}$ B. Szyndler, op. cit., s. 296.

40 Materyały do dziejów Komisyi Rządzacej..., s. 339; AGAD, AKR, nr I.16, s. 9-10, 15-16, 254; nr I.8, s. 13.

${ }^{41}$ AGAD, AKR, nr II.70, s. 14, 16-17.
} 
Wobec niskiej skuteczności dotychczasowych działań przeciwepidemicznych i przeciwepizootycznych władze podjęły dalsze kroki. Komisja Rządząca na sesji 28 sierpnia 1807 r. podjęła następująca rezolucję: „Przełożenie i szrodki użyte od JWW. Dyrektorów Spraw Wewnętrznych i Policji w celu zahamowania szerzącej się w kraju pomórki bydła największą klęskę rolnictwu przynoszącej, uznawszy sprawiedliwemi y przyzwoitemi, gdy te bez użycia dzielnej pomocy wojskowej będa czczemi, zaleciła Komisya W.X. Dyrektorowi Wojny, ażeby zniósł się z JW. Marszałkiem Davout, w celu wyciagnięcia Kordonu zasłaniającego powiaty wolne od zarazy, od okolic zarażonych, y udzielenia pomocy wojskowej wszędy, gdzie tylko JW. Dyrektor Spraw Wewnętrznych do exekucyi swych urzadzeń uzna tego potrzebę" 42 .

Marszałek Davout przychylił się do tej propozycji, ale do utworzenia kordonu prawdopodobnie nie doszło, co spowodowane mogło być barierami organizacyjnymi lub stopniowym ustapieniem zagrożeń dla ludzi i zwierząt. Kordon wojskowy wymagał wielu zabiegów, czyli współdziałania administracji cywilnej ze sztabami wojskowymi, budowy domów na kwarantannę i posterunków ze szlabanami, zorganizowania służb medycznych i weterynaryjnych etc. Podejmowano inne decyzje, nie tak kompleksowe, ale istotne. Przykładowo na wniosek administracji skarbowej zwolniono jadacych do chorych lekarzy i akuszerki od opłaty mostowego na Narwi, Wiśle pod Zakroczymiem i Bugu pod Serockiem ${ }^{43}$.

Mimo stopniowego zaniku zagrożenia epidemicznego jeszcze 2 października 1807 r. Izba Administracji Publicznej departamentu płockiego prosiła o uwolnienie tego terenu od kwaterunku armii francuskiej z powodu zarazy. Niezbyt rozsadnie proponowano, aby kwaterować żołnierzy w miastach, nie we wsiach „z powodu prędszego po miastach ratunku dla przytomnych tamże doktorów i felczerów miejscowych" ${ }^{4}$. Śmiertelność na zapleczu działań wojennych była znaczna. W późniejszym departamencie bydgoskim obliczono, że w 1806 r. urodziło się 15997 osób, zmarło 16784 (zmarło 787 więcej); w 1807 r. urodziło się 16 929, zmarło 26080 (zmarło 9151 więcej); natomiast dla lat pokojowych: w 1808 r. urodziło się 16 900, zmarło 15193 (urodziło się 1707 więcej); w 1809 r. urodziło

\footnotetext{
${ }^{42}$ Materyały do dziejów Komisyi Rządzacej..., s. 368-369.

43 AGAD, AKR, nr I.6, s. 173, 200; Anr II.35, s. 36.

${ }^{44}$ AGAD, AKR, nr II.75, s. 17.
} 
się 16 275, zmarło 12719 (urodziło się 3556 więcej); a w 1810 r. urodziło się 19 987, zmarło 13784 (urodziło się 6203 więcej) ${ }^{45}$.

W tym samym czasie ogniska epidemiczne i epizootyczne powstawały również w innych rejonach kraju. W dniach 6-29 września 1807 r. administracja skarbowa rozliczała delegację doktora medycyny i chirurgii Fryderyka Hoffmana, który przedstawił rachunki na 30 talarów $^{46}$. Doktor Hoffman został wysłany przez dyrektora policji Potockiego do powiatu sochaczewskiego w celu rozpoznania zarazy bydła i ewentualnego użycia wszelkich środków do jej zwalczania. Wysokość wydanej sumy (same diety wyniosły 10 talarów) wskazuje jednak na niewielkie rozmiary epizootii. Dnia 11 września 1807 r. doktor Fryderyk Hildebrand, fizyk (lekarz) powiatu piotrkowskiego, alarmował władze w Warszawie o zagrożeniu epidemicznym w Piotrkowie ${ }^{47}$. Choroba, która doktor Hildebrand określił jako „zaraźliwą malignę”, miała swoje pierwotne ognisko wśród żołnierzy stacjonujaccych w klasztorze dominikanów. Rychło przypadki zachorowań odnotowano wśród ludności cywilnej miasta. W związku $z$ ta sytuacją doktor Hildebrand proponował rozśrodkowanie lazaretu do klasztoru bernardynów i prywatnej posesji.

Ogniska chorób zakaźnych występowały prawdopodobnie częściej, co nie zawsze znalazło potwierdzenie w materiałach źródłowych, nawet odnoszących się do lokalnych społeczności. Przykładem może być sprawa Rozalii Albinowiczowej, która wyasygnowała kwotę 37 talarów i 25 fenigów na uwolnienie „od powietrza” mieszkańców Ostrzeszowa ${ }^{48}$. Problem został rozstrzygnięty na wysokim szczeblu, aż przez Komisję Rządząca, która na wniosek dyrektora Brezy wydała 20 maja 1807 r. zalecenie Izbie Administracji Publicznej departamentu kaliskiego, aby kwota została zwrócona Albinowiczowej ze składek mieszczan ostrzeszowskich. Na zagrożenie epidemiczne wskazywano także przy okazji opisu warunków życia i pracy robotników przy fortyfikacjach w Modlinie. Pracowali oni podczas upałów, 15 godzin dziennie, bez gratyfikacji pieniężnej, jedynie za kawałek chleba. Ogniskiem epidemii mógł

45 Statystyka departamentu bydgoskiego ułożona $w$ m-cu kwietniu 1812 roku, wyd. M. Kallas, J. Wojciak, Poznań 1972, s. 21.

${ }^{46}$ Materyały do dziejów Komisyi Rządzacej..., s. 462; AGAD, AKR, nr I.6, s. 198; nr I.8, s. 82-83; nr II.43, s. 3-5.

47 AGAD, AKR, nr I.17, s. 37-38; nr I.22, s. 51.

48 AGAD, AKR, nr I.13, s. 33-34; nr I.188, s. 5. 
okazać się tamtejszy szpital, gdzie przebywali liczni chorzy „pokaleczeni przez rozmaite zdarzenia przy robotach fortyfikacyjnych" ${ }^{\text {. }}$

Jako miasto stołeczne, szczególnie w Warszawie władze wydawały wiele zarządzeń zmierzających do poprawy stanu sanitarno-zdrowotnego. Jednocześnie rezydent napoleoński w Warszawie Stefan Vincent stwierdził, że w polskiej stolicy brakuje dobrej policji ${ }^{50}$. Dnia 14 kwietnia 1807 r. Magistrat Policji Miasta Warszawy wydał obwieszczenie, w którym opisany został zły wygląd ulic, zawalonych błotem i gnojem oraz niedostateczną liczbę koni w magazynie karowym (czyli remizie wozów wywożących nieczystości), co stwarza zagrożenie epidemiczne ${ }^{51}$. W związku $z$ tym nakazano właścicielom domów, aby w ciągu 10 dni usunęli $z$ posesji i ulic gnój, błoto i śmieci. Po tym terminie groziły kary, a dopilnowanie wykonania obwieszczenia powierzono intendentom cyrkułowym, policjantom i dozorcom.

Prawdopodobnie $\mathrm{w}$ związu $\mathrm{z}$ sytuacja epidemiczna $\mathrm{w}$ departamencie płockim 6 lipca 1807 r. problemem stanu sanitarnego Warszawy zajęła się Komisja Rządząca. Wydała ona następująca rezolucję: „Zalecono JW. Dyrektorowi Policyi, ażeby gdy od ochędóstwa $\mathrm{w}$ mieście y zdrowie mieszkańców zależy, przedsięwziął niezwłocznie przyzwoite y skuteczne szrodki do oczyszczenia w mieście Warszawie ulic y kanałów zarażajacych powietrze szkodliwemi wyziewami kałów, y ponowił rozkazy possesorom chędożenia co tydzień ulic przed swemi domami, które to rozrządzenie do wszystkich miast w kraju ma być rozciagnięte"52. Dyrektor policji Potocki wywiązał się $z$ nałożonego zadania, aczkolwiek w stolicy wozy karowe używano w pierwszej kolejności do oczyszczania lazaretów, zaniedbujac przez to inne posesje oraz ulice i place. Dyrektor Potocki wydał ponadto obwieszczenie o zakazie sprzedaży niedojrzałych owoców ${ }^{53}$.

Dnia 22 lipca 1807 r. dyrektor sprawiedliwości i prezydujący w Dyrektoriacie Generalnym Feliks Łubieński referował zagadnienie epidemii wśród ludności żydowskiej w Warszawie, gdzie dzien-

49 AGAD, AKR, nr II.36, s. 6-9.

50 Instrukcye $i$ depesze rezydentów francuskich $w$ Warszawie 1807-1813, t. I, wyd. M. Handelsman, Kraków 1914, s. 16.

51 „Gazeta Korrespondenta Warszawskiego i Zagranicznego” 1807, nr 30, s. 383.

52 Materyały do dziejów Komisyi Rządzacej..., s. 285; AGAD, AKR, nr I.6, s. 250; nr I.15, s. 367; nr II.63, s. 1; nr II.64, s. 23.

53 AGAD, AKR, nr I.26, s. 22. 
nie umierało po kilkanaście osób ${ }^{54}$. Dyrektor policji Potocki odpowiedział, że jest o tym poinformowany raportem kreismedyka Filipa Franciszka Künzla. Dalej oznajmił, że podjęto odpowiednie działania $\mathrm{w}$ celu powstrzymania dalszych zachorowań, za najważniejsze $z$ nich uważając przesiedlenie części sublokatorów żydowskich do innych dzielnic Warszawy. Nadmierne do tej pory zagęszczenie lokali i ich zły stan sanitarny były zagrożeniem dla zdrowia. Prezes Łubieński zalecił jednak ostrożność w tym postępowaniu, aby przez przesiedlenie Żydów nie rozszerzyć rozmiarów zachorowań. Jest to problem, czy było to rzeczywiste zagrożenie epidemiczne, czy czasem dyskusja na posiedzeniu Dyrektoriatu Generalnego nie wpisywała się w panującą wówczas, w tym również w czasach Księstwa Warszawskiego, politykę ograniczania w prawach ludności żydowskiej ${ }^{55}$. Świetny pretekst do tego kierunku polityki stanowiło zagrożenie epidemiczne.

Na przełomie XVIII i XIX w. najgroźniejszą choroba pozostawała ospa. Kobiety, które na twarzy nie miały charakterystycznych śladów po ospie, uważano za ładne („gładka niewiasta”). Miara zagrożenia ospa może być statystyka przyczyn zgonów w parafii Pławno w powiecie radomszczańskim, gdzie w latach 1795-1799 choroba ta sytuowała się na pierwszym miejscu, powodując 34 zgony na ogólną liczbę 10856. Wiosna 1807 r. Izba Administracji Publicznej departamentu warszawskiego poinformowała za pośrednictwem prasy, że odbierane przez nią raporty wskazuja niezbicie na zwiększanie się śmiertelności dzieci na ospę ${ }^{57}$.

Do tego czasu nie wprowadzono obowiązkowych szczepień. Jedyna metodą wprowadzania szczepień w tym czasie były akcje uświadamiające przez różne instytucje. Przykładowo 15 marca 1807 r. korespondent „Gazety Warszawskiej” relacjonował z Kutna: „Czytaliśmy niedawno jaką gorliwością Xiąże Lukieski [księżna Lukki była siostra Napoleona Eliza Maria Anna z domu Bonapar-

\section{Ibidem.}

55 Szerzej: Z. Filipiak, Ograniczanie praw politycznych $i$ cywilnych ludności żydowskiej w Księstwie Warszawskim, „Studia Iuridica Toruniensia” 2010, t. VI, s. 5-30; id e m, Projekt urządzenia ogólnego ludności żydowskiej w Księstwie Warszawskim z 1808 r., „Czasopismo Prawno-Historyczne” 2016, t. LXVIII, z. 2, s. $147-166$.

56 E. Vielros e, Przyczynek do demografii wsi polskiej $w$ XVIII wieku, „Roczniki Dziejów Społecznych i Gospodarczych” 1952, t. XIV, s. 133.

57 „Gazeta Korrespondenta Warszawskiego i Zagranicznego” 1807, nr 30, s. 382. 
te Baciocchi - przyp. O.G. i T.S.] stara się o wytępienie w państwie swoim ospowej zarazy, naznaczając nadgrody lekarzom, którzy pewną liczbę osób między ludem ospą ochraniającą zaszczepią. Godna jest pochwały ta troskliwość w panujacym, który władzy i bogactw swoich używa dla oszczędzania klęsk ludności. Lecz niemniej wdzięczni być powinniśmy prywatnym, którzy przy małych sposobach poświęcają się dobru bliźnich swoich. Widziemy tu piękny tego przykład w spółziomku naszym Xiędzu Sienickim. Kapłan ten dziesięć lat życia strawiwszy na trudnych obowiązkach nauczyciela w zgromadzeniu Xięży Pijarów, dla osłabionego zdrowia przymuszony ich zaniechać, przyją szczupłe bardzo probostwo w powiecie orłowskim, gdzie cały oddał się na usługi ubogiego ludu. Szczególniej przyłożył się do rozszerzenia ospy ochraniającej i własna ręka zaszczepił przeszło 600 osobom, walcząc z przesądami pospólstwa, które częstokroć dobrodziejów swoich ma za nieprzyjaciół. Spodziewać się należy, iż rząd tego gatunku zasługę cenić i nagrodzić będzie umiał, gdy o niej uwiadomiony zostania"

W 1807 r. największe zagrożenia zdrowotne dla żołnierzy i ludności cywilnej wynikały $z$ prowadzonej wojny. Dlatego zwiększona zapadalność i śmiertelność zauważamy na bezpośrednim zapleczu armii francuskiej i polskiej walczacych na Pomorzu. Natomiast nie były to zagrożenia na skalę spotykana wcześniej, kiedy trzeba było się borykać $z$ epidemiami dżumy ${ }^{59}$, jak również później, w warunkach epidemii cholery. Zagrożenia zdrowotne mobilizowały władze i środowisko lekarskie do działania. Wydane wówczas zarządzenia i podjęte wysiłki organizacyjne kierowane były zarówno na doraźne zwalczanie i zapobieganie chorobom, jak i tworzenie zrębów przyszłych stosunków sanitarno-zdrowotnych.

58 „Gazeta Warszawska” 1807, dodatek do nru 27, s. 430.

${ }^{59}$ Franciszek Gi i d r oy ć umiejscowił jeszcze epidemię dżumy w 1797 r. w miastach Szarogród i Lanckorona oraz na Wołyniu (Mór w Polsce w wiekach ubiegłych. Zarys historyczny, Warszawa 1899, s. 67). Rada Ministrów Księstwa Warszawskiego wielokrotnie debatowała nad ochrona przed zaraza, która grasowała na Krymie i w okolicy Chersonia. Zagadnienia te wymagaja jednak badań archiwalnych (np. w Archiwum Państwowym w Chersoniu znajduja się bogate źródła do tego tematu). 


\section{Bibliografia}

\section{ŹRódea ARChIWALNE}

Archiwum Główne Akt Dawnych w Warszawie [AGAD]

Archiwum Komisji Rządzącej [AKR] nr I.5, I.6, I.8, I.10, I.13, I.15, I.17, I.22, I.26, I.188, II.36, II.41, II.43, II.55, II.62, II.63, II.64, II.75, II.92.

\section{ŹRÓDEA DRUKOWANE}

Archiwum Wybickiego, t. II (1802-1822), wyd. A.M. Skałkowski, Gdańsk 1950.

Białkowski A., Pamiętniki starego żołnierza, Gdynia 2003.

Instrukcye $i$ depesze rezydentów francuskich $w$ Warszawie 1807-1813, t. I, wyd. M. Handelsman, Kraków 1914.

Jaszowski J., Pamiętnik dowódcy rakietników konnych, Warszawa 1968.

Materyały do dziejów Komisyi Rządzacej z r. 1807, t. I (Dziennik czynności Komisyi Rządzacej), wyd. M. Rostworowski, Kraków 1918.

Perzyna L., Lekarz dla włościan, Warszawa 1793.

Statystyka departamentu bydgoskiego ułożona $w$ m-cu kwietniu 1812 roku, wyd. M. Kallas, J. Wojciak, Poznań 1972.

\section{Prasa}

"Gazeta Korrespondenta Warszawskiego i Zagranicznego" 1807, nr 30.

„Gazeta Warszawska” 1807, dodatek do nru 27, nr 30.

\section{Opracowania}

Arnold J.R., Ralp R.R., Kryzys w śniegu. Kampania zimowa 1806-1807. Wielka Armia przeciwko Armii Carskiej, przekł. M. Rukat, red. M. Promis, Oświęcim 2014.

Baranowski M., Chleb z pajęczyna czy "species vulnerariae”? - leczenie ran w wojskach Księstwa Warszawskiego w świetle „Przepisów lekarstw”, „Teka Komisji Historycznej Oddział Lublin PAN" 2010, t. VII, s. 67-77.

Bielecki R., Wielka Armia, Warszawa 1995.

Bincer W., Wojny i choroby zakaźne (Z rozważań epidemiologicznych), Cieszyn 1946.

Filipiak Z., Ograniczanie praw politycznych i cywilnych ludności żydowskiej $w$ Księstwie Warszawskim, „Studia Iuridica Toruniensia” 2010, t. VI, s. 5-30.

Filipiak Z., Projekt urządzenia ogólnego ludności żydowskiej w Księstwie Warszawskim z 1808 r., „Czasopismo Prawno-Historyczne” 2016, t. LXVIII, z. 2, s. $147-166$.

Fleck L., O niektórych swoistych cechach myślenia lekarskiego, „Archiwum Historii i Filozofii Medycyny" 1927, t. VI, s. 55-64. 
Giedroyć F., Mór w Polsce w wiekach ubiegłych. Zarys historyczny, Warszawa 1899.

Giedroyć F., Rys historyczny szpitala św. Łazarza w Warszawie, Warszawa 1897.

Giedroyć F., Służba Zdrowia w dawnem Wojsku Polskiem, Warszawa 1927.

Grzelak E., Chirurgia polowa $w$ Księstwie Warszawskim i Królestwie Polskim, „Studia i Materiały do Historii Wojskowości” 1970, t. XVI, cz. 1, s. 125-231.

Jastrzębowski Z., Polska statystyka medyczna a badania nad zdrowotnościa społeczeństwa polskiego w XIX wieku, „Medycyna Nowożytna. Studia nad Historia Medycyny" 1996, t. III, z. 1-2, s. 117-123.

Krzyś J., Służba zdrowia wojsk polskich w latach 1806-1807, Łódź 1978 (rozprawa doktorska w Bibliotece Wydziału Wojskowo-Lekarskiego Uniwersytetu Medycznego w Łodzi).

Rogacki T., I wojna polska 1806-1807, t. I (Od manewru pułtuskiego do kampanii zimowej $w$ Prusach Wschodnich), Zabrze 2015.

Rogacki T., Pruska Iława 1807, Warszawa 2004.

Srogosz T., Między biologiczna egzystencja człowieka $w$ dziejach a historia nauki, Częstochowa 2003.

Srogosz T., Pomoc weteranom, rannym $i$ chorym na ziemiach polskich $w$ latach 1806-1807, Częstochowa 2001.

Sułek L.A., Dezercja z wojsk Księstwa Warszawskiego (lata 1807-1813), „Kwartalnik Historyczny" 1988, nr 3, s. 173-198.

Summerville Ch., Polska kampania Napoleona, przekł. M. Łakomy, Warszawa 2008.

Szymański J., Nauki pomocnicze historii, Warszawa 2001.

Szyndler B., Stanisław Nałecz Małachowski 1736-1809, Warszawa 1979.

Urłanis B.C., Wojny a zaludnienie Europy, Warszawa 1962.

Vielrose E., Przyczynek do demografii wsi polskiej w XVIII wieku, „Roczniki Dziejów Społecznych i Gospodarczych" 1952, t. XIV, s. 122-136.

Zajewski W., Józef Wybicki, Warszawa 1977.

NOTKA O AUTORACH:

Doc. dr Olga Gaidai - historyk, pracownik Katedry Historii Czarnomorskiego Uniwersytetu Narodowego im. Petra Mohyły w Mikołajowie.

Zainteresowania naukowe: historia medycyny, historia życia codziennego, biografistyka, historia życia i pracy ziemian, historia Ukrainy i Polski w XVIII i na początku XX w.

그osvita13@ukr.net 
Prof. dr hab. Tadeusz Srogosz - historyk, pracownik Instytutu Historii Uniwersytetu Humanistyczno-Przyrodniczego im. Jana Długosza w Częstochowie.

Zainteresowania badawcze: opieka społeczna i zdrowotna oraz dzieje epidemii chorób zakaźnych na ziemiach polskich w XVIII i na początku XIX w., życie codzienne żołnierzy w XVII - na początku XIX w., dzieje prawobrzeżnej Ukrainy w XVIII w., historia historiografii, metodologia historii, zwłaszcza historii medycyny.

ఐ tadeusz@tsrogosz.pl 